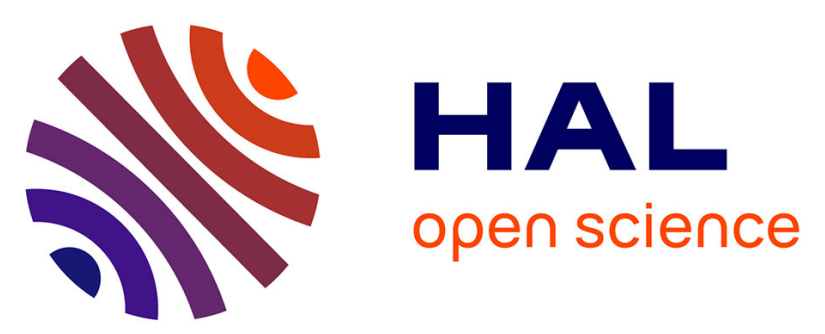

\title{
In situ generated half-lanthanidocene based catalysts for the controlled oligomerisation of styrene: Selectivity, block copolymerisation and chain transfer
}

\author{
Philippe Zinck, Andreia Valente, André Mortreux, Marc Visseaux
}

\section{- To cite this version:}

Philippe Zinck, Andreia Valente, André Mortreux, Marc Visseaux. In situ generated halflanthanidocene based catalysts for the controlled oligomerisation of styrene: Selectivity, block copolymerisation and chain transfer. Polymer, 2007, 48, pp.4609-4614. 10.1016/j.polymer.2007.06.014 . hal-00265032

\section{HAL Id: hal-00265032 \\ https://hal.science/hal-00265032}

Submitted on 18 Mar 2008

HAL is a multi-disciplinary open access archive for the deposit and dissemination of scientific research documents, whether they are published or not. The documents may come from teaching and research institutions in France or abroad, or from public or private research centers.
L'archive ouverte pluridisciplinaire HAL, est destinée au dépôt et à la diffusion de documents scientifiques de niveau recherche, publiés ou non, émanant des établissements d'enseignement et de recherche français ou étrangers, des laboratoires publics ou privés. 


\title{
In situ generated half-lanthanidocene based catalysts for the controlled oligomerisation of styrene: Selectivity, block copolymerisation and chain transfer
}

\author{
Philippe Zinck* , Andreia Valente, André Mortreux, and Marc Visseaux* \\ Synthèses Organométalliques et Catalyse, Unité de Catalyse et Chimie du Solide, UMR CNRS \\ 8181, ENSCL, Cité Scientifique, 59652 Villeneuve d'Ascq, France. E-mail : philippe.zinck@,ensc- \\ lille.fr, marc.visseaux@ensc-lille.fr
}

\begin{abstract}
The $\mathrm{Cp} * \mathrm{Nd}\left(\mathrm{BH}_{4}\right)_{2}(\mathrm{THF})_{2} / n$-butylethylmagnesium combination affords a controlled "living" and syndioselective oligomerisation of styrene. The living oligostyrenes can be used as macromonomers for block copolymerisation, leading to the unprecedented synthesis of a (polystyrene)-block-(1,4-trans polyisoprene) copolymer. Reversible transmetallation between the neodymium and the magnesium atom is further established with a transfer efficiency close to $100 \%$.
\end{abstract}

Keywords : Polymer chemistry, block copolymerisation, transfer reactions.

\section{Introduction}

The syndiotactic polymerisation of styrene reported for the first time 20 years ago [1] is now well-documented. If titanium based precatalysts combined to alumoxanes have been studied extensively, with an emphasis on half-titanocenes [2,3], the discovery of a highly syndiospecific living system has only been reported recently using half-calciumocenes $[4,5]$. Besides, the search for new versatile catalysts affording copolymerisations has found a new breath with the rare earth elements, using the strategy of changing the ligand environment of the metal [6-9]. Simple rare earth precatalysts in combination with a cocatalyst have also been applied successfully to the polymerisation of styrene [10-13] as well as half-lanthanidocenes [9;14,15], lanthanidocenes [16,17] and allyl complexes $[17,18]$. Only one lanthanide mediated controlled "living" polymerisation of styrene has been reported so far to our knowledge, leading to the unprecedented incorporation of syndiotactic sequences in styrene-ethylene copolymers $[14,15]$. 
Borohydrido lanthanide complexes are an emerging class of simple polymerisation precatalysts. They are known as valuable precursors in organometallic chemistry, give rise to well-defined X-ray characterized compounds, are more reactive and more soluble than their chloro homologues, and allow ${ }^{1} \mathrm{H}$ NMR monitoring [19-23]. Another reason for the growing interest in borohydrido catalysts lies in their versatility and the related applicative potentialities for copolymerisations. They are indeed known as precatalysts for the polymerisation of dienes [24-25] and olefins [26] as well as initiators for polar monomers such as cyclic esters [27] and acrylates [28,29]. We reported recently the polymerisation of styrene by trisborohydrido complexes of the rare earths [30] and we present herein, in the course of our on-going research, preliminary results of the activity of an in-situ generated bisborohydrido half-neodymocene. This system affords not only a controlled "living" oligomerisation of styrene, that leads to the unprecedented synthesis of a polystyrene block - [1,4-trans polyisoprene (98\%)] copolymer, but also well-controlled reversible chain transfer to magnesium.

\section{Experimental section}

\subsection{Materials}

All operations were performed under dry argon by using Schlenk techniques. Toluene was dried over sodium / benzophenone and distilled over molecular sieves before use. Styrene (99\% from Aldrich) was dried over calcium hydride, distilled twice over molecular sieves and once just before use. $n$-butylethylmagnesium (20\% wt. in heptane from Texas Alkyl) was used as received. The complex $\mathrm{Cp} * \mathrm{Nd}\left(\mathrm{BH}_{4}\right)_{2}(\mathrm{THF})_{2}$ was synthesized according to literature procedures [31-32].

\subsection{Polymerisation}

In a glove box, the borohydrido complex was weighed into a vessel. Toluene, styrene and $n$-butylethylmagnesium were added in the flask in this order using syringes. The mixture was magnetically stirred at the reaction temperature for a given time, diluted in toluene and the resulting solution was poured into ethanol, leading to the precipitation of an off-white polymer. Solvents were evaporated under partial vacuum, and the product was dried under vacuum for $48 \mathrm{~h}$.

For the copolymerisation experiments and the subsequent styrene addition, the flask was reintroduced in the glove box after the first run of the reaction $\left(20 \mathrm{~h}\right.$ at $\left.50^{\circ} \mathrm{C}\right)$. Half of the mixture was separated for analysis and $1 \mathrm{ml}$ monomer (isoprene or styrene) was introduced in the second half remaining in the flask. After the given reaction time, $(2 \mathrm{~h}$ for 
isoprene and $20 \mathrm{~h}$ for styrene, $50^{\circ} \mathrm{C}$ ) the procedure described above was used to isolate the product.

\subsection{Measurements}

The ${ }^{1} \mathrm{H}$ spectrum of 1,4-trans polyisoprene was recorded on a AC 300 Bruker spectrometer at room temperature in $\mathrm{CDCl}_{3}$. Other spectra were recorded on a $\mathrm{AC} 400$ Bruker spectrometer at $380 \mathrm{~K}$ and $400 \mathrm{~K}$ in tetrachloroethane- $d 2$. The chemical shifts were calibrated using the residual resonances of the solvent. Size exclusion chromatography (SEC) was performed (i) in THF as eluent at $20^{\circ} \mathrm{C}$ using a Waters SIS HPLC-pump, a Waters 410 refractometer and Waters styragel column (HR2, HR3, HR4, HR5E) and (ii) in trichlorobenzene as eluent at $135^{\circ} \mathrm{C}$ using a Waters $150 \mathrm{C}$ PLUS device with coupled refractometer and viscosity detectors. The number-average molecular weight and polydispersity index were calculated using polystyrene standards. Both analyses lead to similar results for all entries except entry 4 where a number-average molecular weight of 11000 and a PDI of 1.6 was measured at room temperature.

\section{Results and discussion}

Typical experiments conducted in toluene at $50^{\circ} \mathrm{C}$ are summarized Table 1 . The reaction is quantitative in several hours and syndioselective ( $85 \%$ from NMR as detailed in

Table 1

Polymerisation of styrene with $\mathrm{Cp} * \mathrm{Nd}\left(\mathrm{BH}_{4}\right)_{2}(\mathrm{THF})_{2}$ and $n$-butylethylmagnesium

\begin{tabular}{llllllll}
\hline Entry $^{\mathrm{a}}$ & St/Nd & $\mathrm{Mg} / \mathrm{Nd}$ & $\begin{array}{l}\text { Time Conversion } \\
(\mathrm{h})\end{array}$ & $\begin{array}{l}\bar{M}_{n} \mathrm{calc}^{\mathrm{b}} \\
(\%)\end{array}$ & $\begin{array}{l}{\overline{M_{n}}}^{\mathrm{c}} \\
(\mathrm{g} / \mathrm{mol})\end{array}$ & PDI $^{\mathrm{d}}$ \\
\hline 1 & 100 & 1 & 2 & 31 & 1600 & 1400 & 1.3 \\
2 & 108 & 1.05 & 8 & 59 & 3100 & 2700 & 1.2 \\
3 & 100 & 1 & 20 & 97 & 5000 & 3800 & 1.3 \\
4 & 440 & 1 & 20 & 81 & 18500 & 16000 & 1.2 \\
5 & 440 & 10 & 20 & 24 & 550 & 560 & 1.2 \\
6 & 475 & 10.8 & 90 & 99 & 2300 & 2100 & 1.3 \\
7 & 2000 & 10 & 90 & 82 & 8500 & 8300 & 1.2
\end{tabular}

\footnotetext{
${ }^{\text {a }}$ Reactions conducted at $50^{\circ} \mathrm{C}$ with $0.5 \mathrm{ml}$ styrene in $0.5 \mathrm{ml}$ toluene

${ }^{\mathrm{b}}$ Expected molecular weight assuming two growing chains per magnesium

${ }^{c}$ Number-average molecular weight measured by SEC
} 
${ }^{\mathrm{d}}$ Polydispersity index measured by SEC $\left(\mathrm{PDI}=\overline{M_{w}} / \overline{M_{n}}\right)$

the appendix). The analysis of the molecular weight distribution shows a rather low and constant polydispersity along the reaction time (entries 1-3), indicating a well-controlled oligomerisation. The resulting molecular weights are close to the theoretical ones assuming two growing chains per magnesium, i.e one growing chain per alkyl group. The living character of the reaction was checked by a second addition of monomer after $20 \mathrm{~h}$ reaction. A small amount of deactivated chains can be noticed Figure 1, characteristic of apparently living or "living" systems [33-34]. The higher apparent polydispersity observed after the second addition of styrene (Figure 1a) can be attributed to the presence of such deactivated chains. The selectivity of the reaction was found to be unchanged.

Figure 1

Molecular weight distribution of polystyrene (conditions similar to entry 3 ) before (dot lines) and after subsequent addition of styrene (a) or isoprene (b)

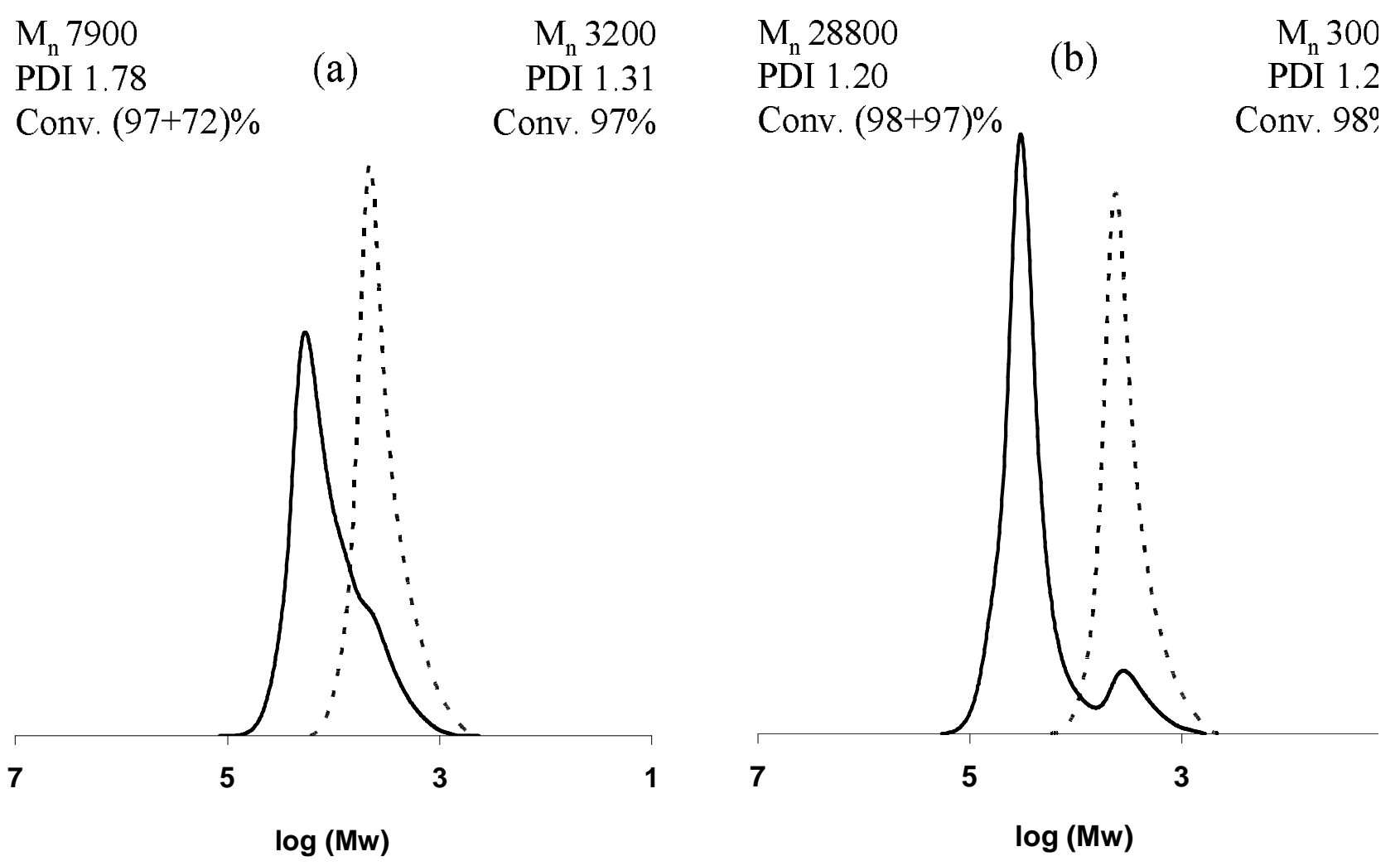

The potentiality of those "living" oligostyrenes as macroinitiators for block copolymerisation was assessed with isoprene (Figure $1 \mathrm{~b}$ ), and the resulting polyisoprene block shows a high 1,4-trans microstructure (98\% from NMR analysis detailed in the appendix), together with a narrow polydispersity (1.2). Such a polystyrene-block-(1,4trans polyisoprene) copolymer has never been synthesized so far to our knowledge. 
The occurrence of transmetallation is further established by increasing the $\mathrm{Mg} / \mathrm{Nd}$ ratio up to 10 (entries 5-7 in Table 1). The reaction is slower (entries 5-6), but remains quantitative. The narrow polydispersity and the control over the molecular weight are preserved in the course of the transfer reactions. The selectivity was found to be unchanged, in accordance with coordination - insertion processes taking place around the neodymium atom. All alkyl fragments of $n$-butylethylmagnesium introduced are involved in the chain transfer, highlighting a process which can be considered as a polystyrene catalyzed chain growth $[35,36]$ on magnesium. If polyethylene catalyzed chain growth on magnesium [35] and zinc [36] has been achieved, polystyrene chain transfer to aluminium [37,38] and fast and reversible transfer to magnesium $[13,16]$ occurred only with a partial transfer efficiency. A polystyrene catalyzed chain-growth on a metal has never been reported as far as we know, and may pave the way for chain shuttling polymerization [40] regarding the transfer potentialities of lanthanides complexes / dialkylmagnesium combination with respect to ethylene [35] or $\alpha$-olefins [39]. Our interest lies also in the elucidation of the mechanism involved and in the characterization and valorisation of polystyrene-block-(1,4-trans polyisoprene) copolymers.

\section{Conclusion}

The oligomerisation of styrene using $\mathrm{Cp} * \mathrm{Nd}\left(\mathrm{BH}_{4}\right)_{2}(\mathrm{THF})_{2} / n$-butylethylmagnesium presents the following features:

- A controlled character, both in terms of molecular weight and polydispersity,

- A pseudo-living character,

- A syndioselectivity close to $85 \%$,

- Reversible transmetallation with a transfer efficiency close to $100 \%$.

This versatile catalytic system affords finally the synthesis of new polystyrene-block-(1,4trans polyisoprene) copolymers.

\section{Aknowledgments}

The Région Nord-Pas-de-Calais is gratefully acknowledged (ARCIR Nanocat project). We thank Catherine Meliet for NMR studies and Anne-Marie Cazé for GPC measurements. 


\section{References}

[1] Ishihara N., Seimiya T., Kuramoto M., Hoi M. Macromolecules 1986;19: 2464-2465.

[2] Po R., Cardi N., Prog. Polym. Sci. 1996; 21: 47-88.

[3] Tomutsu N., Ishihara N., Newman T.H., Malanga M.T., J. Mol. Catal. 1998, 128, 167190.

[4] Harder S., Feil F., Knoll K., Angew Chem. Int. Ed. 2001; 40: 4261-4264.

[5] Harder S., Feil F., Organometallics 2002; 21: 2268-2274.

[6] Shapiro P.J., Cotter W.D., Schaefer W.P., Labinger J.A., Bercaw J.E., J. Am. Chem. Soc. $1994 ; 116: 4623-4640$.

[7] Hou Z., Zhang Y., Tezuka H., Xie P., Tardif O., Koizumi T., Yamazaki H., Wakatsuki Y., J. Am. Chem. Soc. 2000; 122: 10533-10543.

[8] Hulzsh K.C., Voth P., Beckerle K., Spaniol T.P., Okuda J., Organometallics 2000; 19: 228-243.

[9] Tanaka K., Furo M., Ihara E., Yasuda H., J. Polym. Sci., Polym. Chem. 2001; 39: 13821390.

[10] Yang M., Cha C., Shen Z., Polym. J. 1990; 22: 919-923.

[11] Kaita S., Kobayashi E., Sakakibara, S., Aoshima S., Furukawa J., J. Polym. Sci., Polym. Chem. 1996; 34: 3431-3434.

[12] Hayakawa T., Nakayama Y., Yasuda H., Polym. Int. 2001; 50: 1260-1264.

[13] Sarazin Y, Chenal T., Mortreux A., Vezin H., Carpentier J.F., J. Mol. Catal. A 2005; 238: $207-214$.

[14] Luo Y., Baldamus J., Hou Z., J. Am. Chem. Soc. 2004; 126: 13910-13911.

[15] Hou Z., Luo Y., Li X., J. Organomet. Chem. 2006, 691, 3114-3121

[16] Bogaert S., Carpentier J.F., Chenal T., Mortreux A., Ricart G., Macromol. Chem. Phys. $2000 ; 201: 1813-1822$.

[17] Kirillov E., Lehmann C.W., Razavi A., Carpentier J.F., J. Am. Chem. Soc. 2004 ; 126 : 12240-12241.

[18] Barbier-Baudry D., Camus E., Dormond A., Visseaux M., Appl. Organometal. Chem. $1999 ; 13: 813-817$.

[19] Soloveichik G.L., New J. Chem. 1995; 19: 597-618.

[20] Qian C.T., Zou G., Nie W., Sun J., Lemenovski D.A. and Borzov M.V., Polyhedron 2000; 19: 1955-1959.

[21] Barbier Baudry D., Blacque O., Hafid A., Nyassi A., Sitzmann H., Visseaux M., Eur. J. Inorg. Chem. $2000 ; 11: 2333-2336$. 
[22] Bonnet F., Visseaux M., Hafid A., Barbier-Baudry D., Vigier E., Kubicki M.M., Inorg. Chem. 2004; $43: 3682-3690$.

[23] Guillaume S.M., Le Gland G., Nierlich M., Ephritikhine M., Organometallics 2000 ; $19: 5654-5660$.

[24] Bonnet F., Visseaux M., Pereira A., Barbier-Baudry D., Macromolecules 2005 ; 38 : 3162-3170.

[25] Zinck P., Barbier-Baudry D., Loupy A., Macromol. Rapid Commun. 2005 ; 26 : 46-51. [26] Visseaux M., Chenal T., Roussel P., Mortreux A.., J. Organomet. Chem. 2006, 691, 86-92.

[27] Guillaume S.M., Schappacher M., Soum A., Macromolecules 2003 ; 36 : 54-60.

[28] Bonnet F., Hillier A.C., Collins A., Duberley S.R., Mountford P., Dalton Trans. 2005; 421-423.

[29] Barbier-Baudry D., Bouyer F., Madureira Bruno A.S, Visseaux M., Appl. Organomet. Chem $2006 ; 20: 24-31$.

[30] Zinck P., Visseaux V., Mortreux A., Z. Anorg. Allg. Chem. 2006 ; 632 : 1943-1944.

[31] Guillaume S.M., Le Gland G., Nierlich M., Ephritikhine M., Organometallics 2000, 19, 5654-5660.

[32] Bonnet F., Visseaux M., Hafid A., Barbier-Baudry D., Vigier E. Kubicki M.M., Inorg. Chem. $2004 ; 43: 3682-3690$.

[33] Matyjaszewski K., Macromolecules 1993 ; 26 : 1787-1788.

[34] Matyjaszewski K., Mueller A.H.E/, Macromolecular Nomenclature Note 12, http://www.polyacs.org/main/ nomenclature.html

[35] Pelletier J.F., Mortreux A., Olonde Bujadoux K., Angew. Chem. 1996; 35: 1854-1856.

[36] Britovsek G.J.P., Cohen S.A., Gibson V.C., Van Meurs M., J. Am. Chem. Soc. 2004 ; $126: 10701-10712$.

[37] Newman T.H., Borodychuk K.K. (Dow Chemical Co. USA), Patent US 5428120

[38] Po R., Cardi N., Abis L. Polymer 1998; 39:959-964.

[39] S. Bogaert, T. Chenal, A. Mortreux, G. Nowogrocki, C.W. Lehmann, J.F. Carpentier, Organometallics 2001; 20:199-205.

[40] Arriola D.J., Carnahan E.M., Hustad P.D., Kuhlman R.L., Wenzel T.T., Science 2006; 312: 714-719.

[41] F. Feil, S. Harder, Macromolecules 2003; 36: 3446-3448. 


\section{Appendix - Spectroscopic data}

Determination of the selectivity of the reaction.

Figure A1.

${ }^{13} \mathrm{C}$ NMR spectra of polystyrene (400K in tetrachloroethane- $d 2$ ) in the phenyl ipso carbon region corresponding to atactic polystyrene (a) and syndiotactic-rich polystyrene synthesized using the $\mathrm{Cp} * \mathrm{Nd}\left(\mathrm{BH}_{4}\right)_{2}(\mathrm{THF})_{2} / n$-butylethylmagnesium combination .

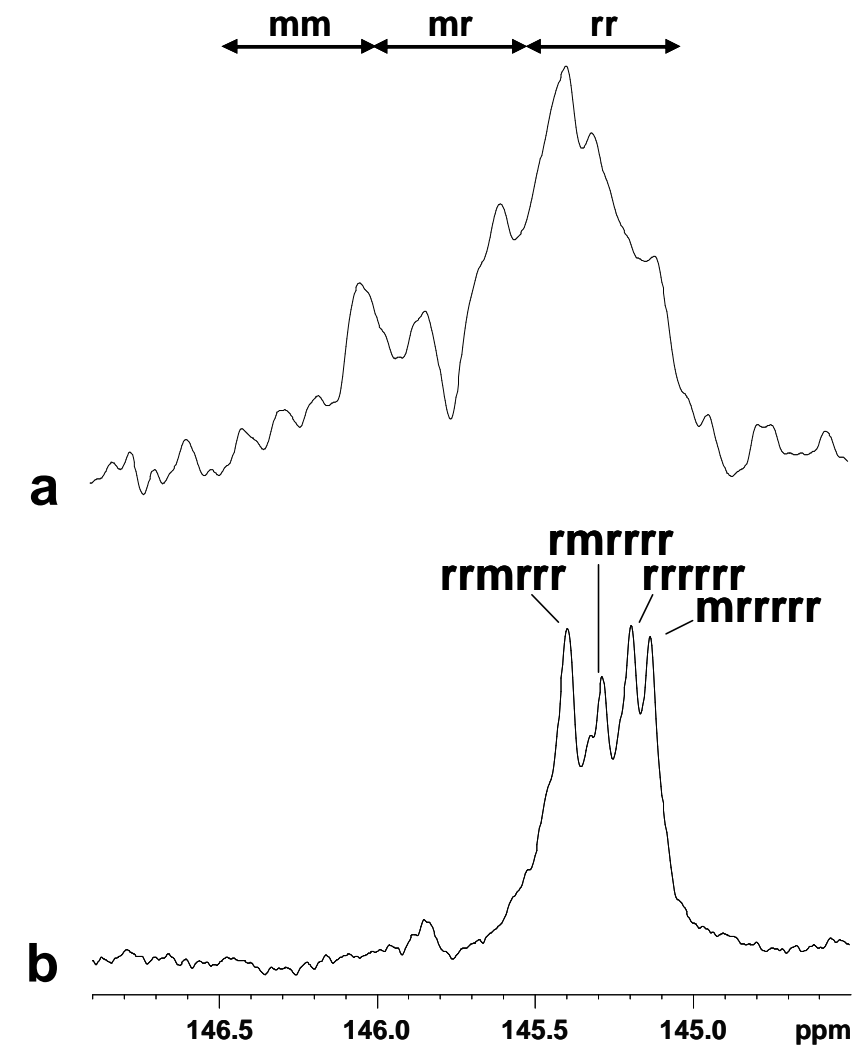

The selectivity of the reaction can be established from the ${ }^{13} \mathrm{C}$ NMR spectra in the phenyl ipso carbon region: the four heptads of highly syndiotactic polystyrene [41] can be distinguished Figure A1. The deconvolution of the spectra is done directly by the NMR software TOPSPIN (Bruker), and leads to the following area proportions of the four heptads, from left to right : $50.4,11.2,20.6$ and $17.8 \%$. It leads to a syndiotacticity ratio of $86.8 \%$, that we consider to be close to $85 \%$. The goodness of fit can be appreciated graphically Figure A2. 
Figure A2.

Deconvolution: experimental vs. fitted curve.

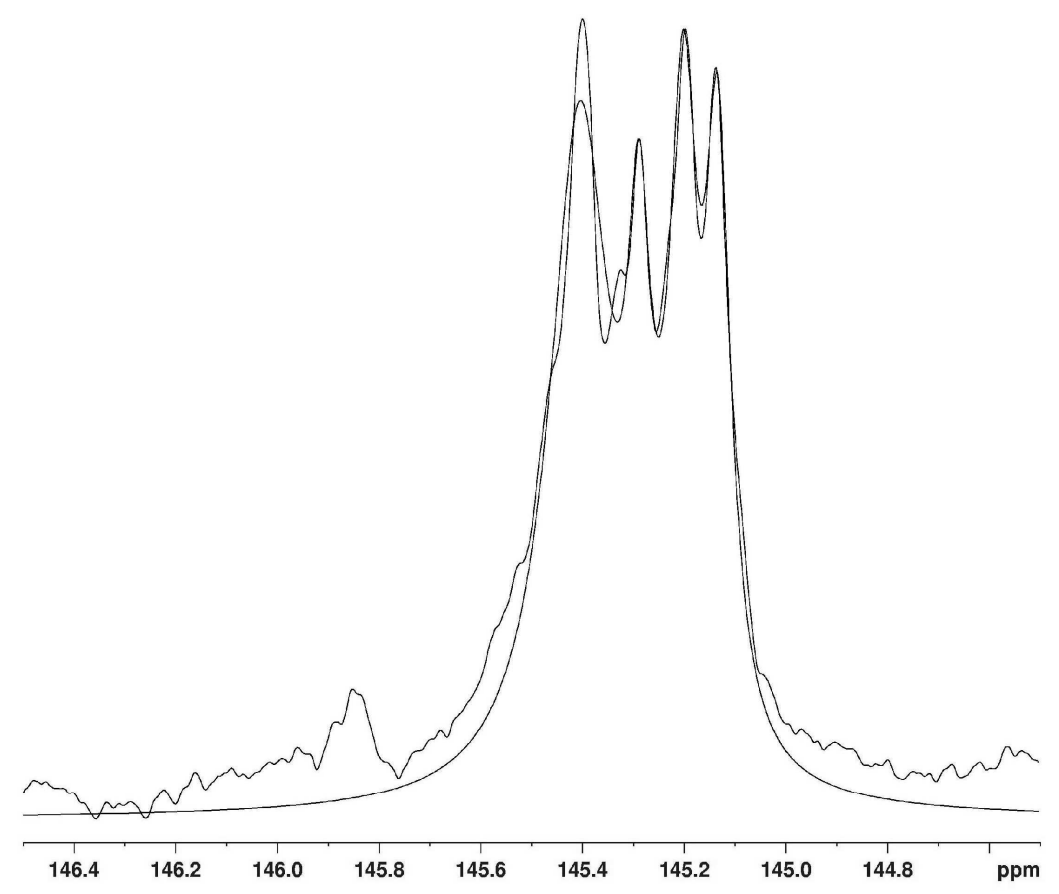

Polystyrene-block-[1,4-trans polyisoprene]

The microstructure of the polyisoprene block was determined from NMR spectra according to the following way. The proportion of 1,4 vs. 3,4 sequences is deduced from the $=\mathrm{CH}$ vs. $=\mathrm{CH}_{2}$ ratio determined from the ${ }^{1} \mathrm{H}$ NMR spectrum. From Figure A3, a $98 \%$ 1,4 microstructure is assessed for the polyisoprene block, but the presence of styrene signals in the $-\mathrm{CH}_{3}$ zone do not enable a quantitative analysis. The absence of signals that would result from 1,4-cis sequences on the ${ }^{13} \mathrm{C}$ NMR spectra (Figure A4) let us conclude to a $98 \%$ 1,4-trans and 2\% 3,4 microstructure for the polyisoprene block. 
Figure A3

${ }^{1} \mathrm{H}$ NMR spectrum of (a) a 98\% 1,4-trans polyisoprene at room temperature in $\mathrm{CDCl}_{3}$ and (b) a polystyrene-block-polyisoprene showing a 1,4-trans microstructure $(380 \mathrm{~K}$, tetrachloroethane- $d 2$ ) - Both compounds were synthesized using the $\mathrm{Cp} * \mathrm{Nd}\left(\mathrm{BH}_{4}\right)_{2}(\mathrm{THF})_{2} /$ $n$-butylethylmagnesium combination.

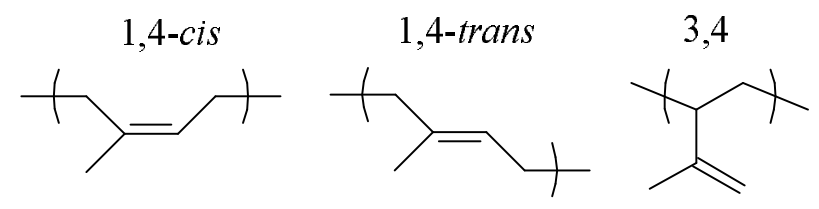

(a)
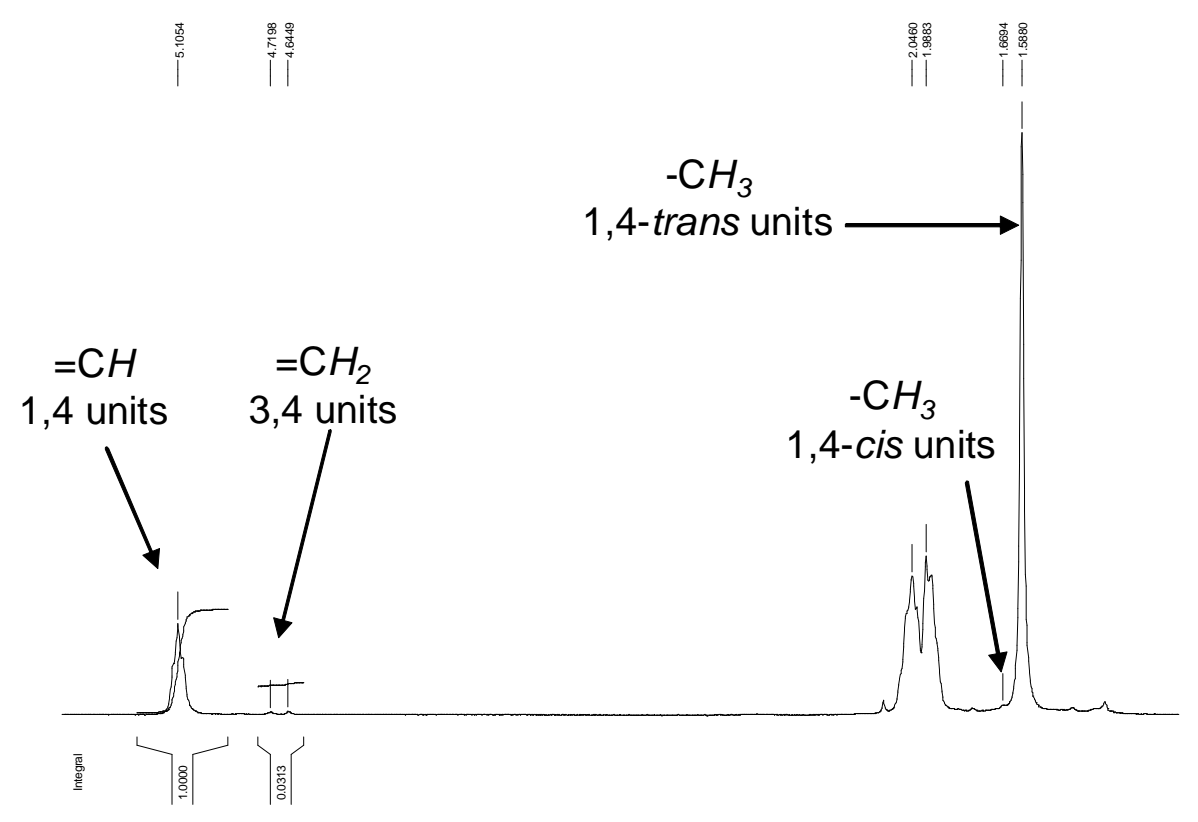

(b)

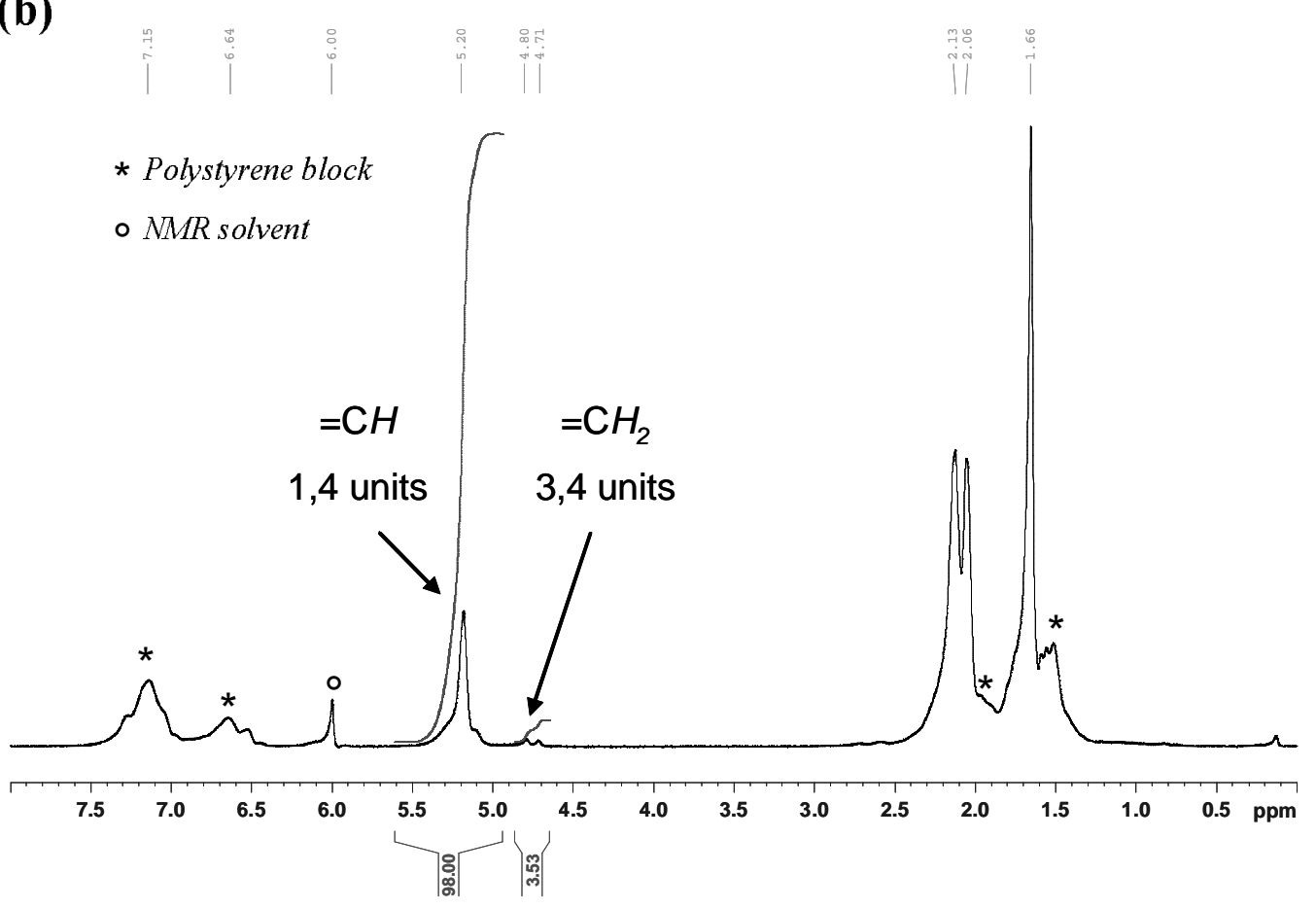


Figure A4

${ }^{13} \mathrm{C}$ NMR spectrum (380K, tetrachloroethane- $d 2$ ) of a polystyrene-block-polyisoprene showing the absence of 1,4-cis units in the polyisoprene block.
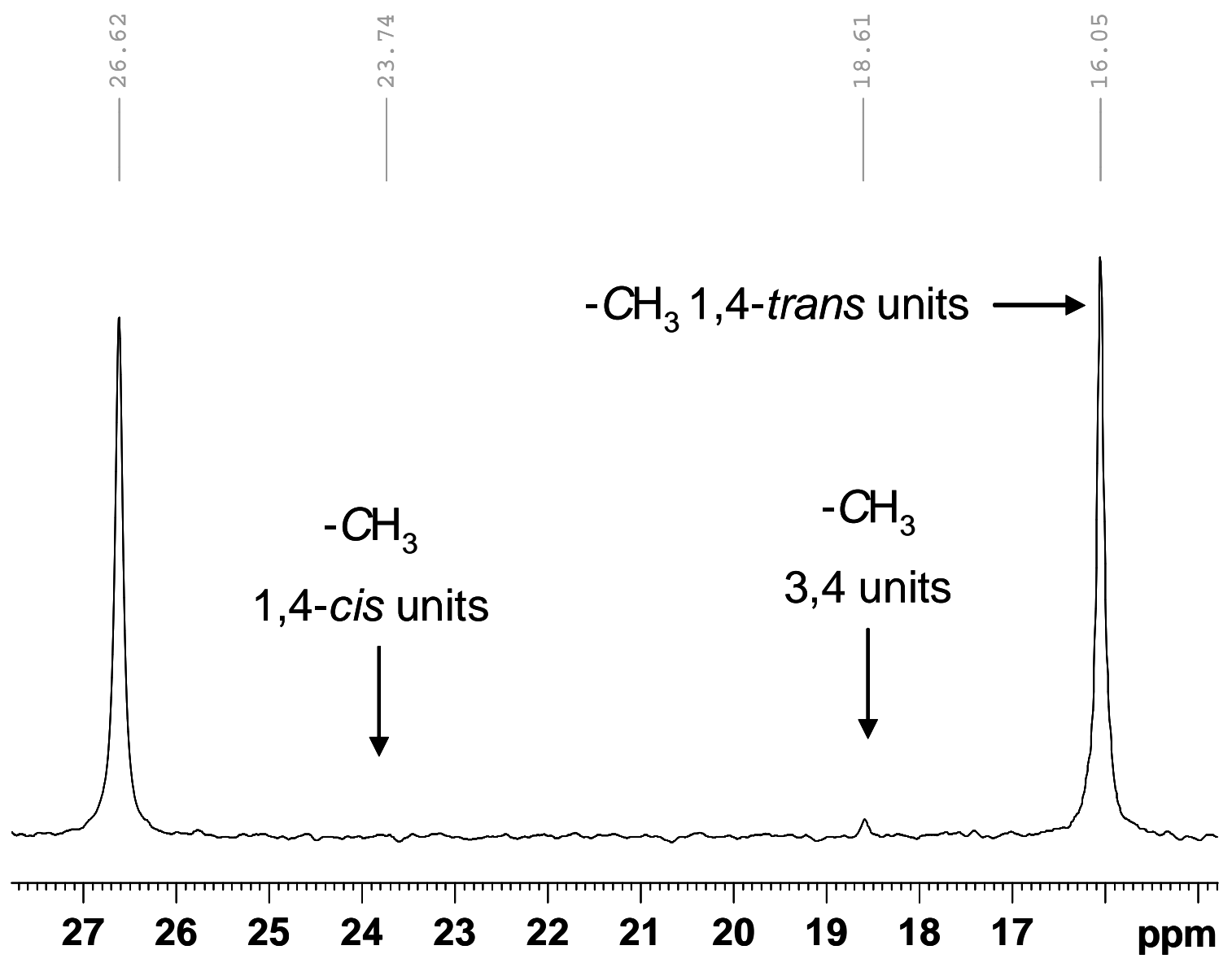